\title{
KEMAMPUAN BERPIKIR KRITIS DAN KETERAMPILAN PROSES DALAM PEMBELAJARAN SIKLUS BELAJAR 7E BERBASIS KEARIFAN LOKAL
}

\author{
Ni Putu Sri Ratna Dewi'1, I Made Citra Wibawa², Ni Luh Pande Latria Devi ${ }^{3}$ \\ 1Jurusan Pendidikan Biologi, Universitas Pendidikan Ganesha, Indonesia \\ 2Jurusan Pendidikan Gurur Sekolah Dasar, Universitas Pendidikan Ganesha, \\ Indonesia \\ 3Jurusan Pendidikan IImu Pengetahuan Alam, Universitas Pendidikan \\ Ganesha, Indonesia
}

e-mail: ratna_lovina@yahoo.com¹,

\begin{abstract}
Abstrak
Tujuan dari penelitian ini adalah untuk mengetahui perbedaan kemampuan berpikir kritis dan keterampilan proses antara kelompok siswa yang dibelajarkan dengan model siklus belajar 7E berbasis kearifan lokal dengan kolompok siswa yang dibelajarkan model pembelajaran konvensional. Signifikansi penelitian terkait dengan pembelajran IPA di sekolah dasar masih menekankan pada hafalan dan jarang melatih keterampilan berpikir tingkat tinggi siswa, sehingga kurang sejalan dengan tujuan pembelajaran IPA. Populasi sebanyak 71 orang, sedangkan sampel yang digunakan sebanyak 58 orang. Rancangan penelitian menggunakan Pretest-posttes Control Group Design. Instrument dalam penelitian ini adalah tes kemampuan berpikir kritis, dan tes keterampilan proses siswa. Data dianalisis dengan teknik MANOVA. Hasil penelitian menunjukan terdapat perbedaan kemampuan berpikir kritis dan keterampilan proses yang signifikan antara siswa yang dibelajarkan dengan model siklus belajar 7E berbasis lokal genius dan yang dibelajarkan dengan model konvensional.
\end{abstract}

Kata kunci: Siklus belajar 7E, Kearifan Lokal, Berpikir Kritis, Keterampilan Proses

\begin{abstract}
The purpose of this study was to determine differences in the ability of critical thinking and process skills among groups of students that learned the $7 \mathrm{E}$ learning cycle model based on local wisdom with students that learned kolompok conventional learning models. Significance pembelajran research related to science in primary schools is focused on memorization and rarely train high-level thinking skills of students, making it less in line with the purpose of learning science. The population of as many as 71 people, while the samples used were 58 people. The study design using pretest-posttes Control Group Design. Instrument in this research is to test the ability of critical thinking, and process skills test students. Data were analyzed by using MANOVA. The results showed there were differences in the ability of critical thinking and process skills significantly between students that learned with the learning cycle model 7E based on local wisdom and that learned to conventional models.
\end{abstract}

Keywords: 7E learning cycle, local wisdom, critical thinking and process skills

\section{PENDAHULUAN}

IPA merupakan salah satu mata pelajaran yang sangat penting untuk dibelajarkan kepada siswa. Tujuan pokok dari pelajaran IPA di sekolah dasar berdasarkan Permendikbud Nomor 22 Tahun 2006 adalah agar: 1) siswa mampu mengembangkan pengetahuan dan pemahaman konsepkonsep IPA yang bermanfaat dan dapat diterapkan dalam kehidupan sehari-hari, 2) mengembangkan rasa ingin tahu, sikap positif dan kesadaran tentang adanya hubungan yang saling 
mempengaruhi antara IPA, lingkungan, teknologi dan masyarakat, 3) mengembangkan keterampilan proses untuk menyelidiki alam sekitar, memecahkan masalah, dan membuat keputusan 4) mempunyai minat untuk mengenal dan mempelajari bendabenda atau kejadian di lingkungan sekitar, dan 5) meningkatkan kesadaran untuk berperan serta dalam memelihara menjaga dan melestarikan lingkungan alam.

Ketika siswa mampu memahami konsep, mengembangkan rasa ingin tahu, memiliki keterampilan proses dan mampu memecahkan permasalahan menggunakan pemahaman yang telah dimiliki maka dapat dikatakan siswa sudah memiliki kemampuan berpikir kritis. Ketika siswa mampu memahami konsep, mengaplikasikan konsep untuk memecahkan masalah maka secara tidak langsung ia sudah memiliki kemampuan berpikir kritis. Banyak ahli yang memberikan definisi terhadap kemampuan berpikir kritis. Menurut Jonson (2010) berpikir kritis merupakan sebuah proses yang terarah dan jelas yang digunakan dalam kegiatan mental seperti pemecahan masalah, mengambil keputusan, merujuk, menganalisis asumsi dan melakukan penelitian ilmiah. Berdasarkan pendapat tersebut maka dapat diartikan bahwa ketika siswa mampu memahami suatu konsep atau pengetahuan dengan baik, secara tidak langsung ia akan mampu memecahkan permasalahan dengan mengaplikasikan konsep yang dimiliki untuk mengambil suatu keputusan yang akan digunakan memecahkan permasalahan yang dihadapi dengan baik, maka siswa tersebut sudah memiliki kemampuan berpikir kritis.

Proses pembelajaran IPA di sekolah dasar hendaknya memberikan kesempatan sebanyak-banyaknya kepada siswa untuk mengembangkan keterampilan proses. Dengan keterampilan proses siswa berupaya menemukan dan mengembangkan konsep dalam materi ajaran. Konsepkonsep yang telah dikembangkan itu berguna untuk menunjang pengembangan kemampuan selanjutnya. Interaksi antara kemampuan dan konsep melalui proses belajar mengajar selanjutnya mengembangkan sikap dan nilai pada diri siswa, misalnya kreativitas, kritis, ketelitian, dan kemampuan memecahkan masalah (Hamalik, 2008). Pemberian pengalaman belajar secara langsung sangat ditekankan melalui penggunaan dan pengembangan keterampilan proses dan sikap ilmiah dengan tujuan untuk memahami konsep-konsep dan mampu memecahkan masalah. Membelajarkan IPA pada siswa sakan lebih menarik dan bermakna jika dalam proses penyampaian materi digunakan hal, peristiwa atau masalah yang nyata terjadi dalam kehidupan siswa seharihari. Hal ini sesuai dengan hasil penelitian yang dilakukan oleh Sornsakda et al (2009) yang menyatakan bahwa menggunakan lingkungan sekitar dalam belajar, dengan model siklus belajar 7E dengan tehnik metakognisi dan pendekatan Handbook mampu meningkatkan keterampilan proses terpadu dan berpikir kritis siswa. Sejalan dengan hasil penelitian Sornsakda et al, hasil penelitian Chankian, Singseewo, dan Thamsananupap (2012) menyatakan pengembangan kurikulum berbasis lingkungan efektif digunakan untuk meningkatkan keterampilan proses dan kemampuan berpikir kritis siswa.

Untuk membantu siswa lebih memahami konsep-konsep IPA serta mengembangkan keterampilan proses dapat digunakan budaya lokal atau kearifan local yang berkembang di masyarakat atau di suatu daerah. Seperti halnya yang dinyatakan oleh Brooks \& Brooks (1999) di mana ia percaya bahwa pendekatan pembelajaran berbasis budaya dapat memberikan kesempatan kepada peserta didik untuk menciptakan makna dan mencapai pemahaman terpadu atas informasi keilmuan yang diperolehnya, serta penerapan informasi keilmuan tersebut dalam konteks permasalahan komunitas budayanya (Sutarno, 2004).

Salah satu bentuk kearifan lokal yang dimiliki masyarakat adat adalah 
dengan menyucikan beberapa tempat yang dijadikan tempat persembahyangan (pura) dan beji (umumnya berupa sumber mata air) sebagai tempat yang disucikan. Dengan disucikannya tempat-tempat tersebut masyarakat tidak akan berani melakukan hal-hal yang dapat merusak kesucian tempat tersebut. Selain itu kearifan lokal yang juga relevan untuk diintegrasikan dalam pembelajaran IPA di SD adalah upacara tumpek wariga dan tumpek uye, kedua upacara ini menekankan pada saling mengasihi antara sesama mahkluk hidup yaitu tumbuhan dan hewan. Hal ini dapat diartikan suatu bentuk sikap mencintai dan menyayangi lingkungan guna menjaga keseimbangan antara manusia dengan lingkungan. Keyakinan pada hal tersebut yang diwariskan secara turuntemurun menjadikan sumber daya alam tetap lestari. Pemahaman tentang nilainilai kearifan lokal penting dimiliki siswa, kini dan pada masa yang akan datang. Ketika siswa tahu makna dari upacara tumpek wariga dan tumpek uye, secara tidak langsung akan menumbuhkan keinginan mereka untuk ikut berpartisipasi dalam upacara tersebut sehingga siswa menjadi bagian dalam menjaga kelestarian alam. Oleh karena itu, nilai-nilai kearifan lokal masyarakat tradisional yang dikembangkan dalam konteks kekinian, penting untuk dijadikan kajian dalam pembelajaran IPA sehingga terinternalisasi pada diri siswa.

Pada kenyataannya proses pembelajaran IPA disekolah belum menunjukan hasil yang maksimal. Hal ini dibuktikan dengan hasil observasi yang dilakukan pada tanggal 11 Oktober 2015 di gugus II Kecamatan Marga, Kabupaten Tabanan. Observasi dilakukan di SDN 1 Petiga dan SDN 3 Petiga. Lokasi sekolah tersebut terletak di Desa Petiga, kurang lebih berjarak 5 $\mathrm{km}$ dari kecamatan marga dan $30 \mathrm{~km}$ dari pusat kota Kabupaten Tabanan. Desa Petiga merupakan salah satu desa yang sangat menjaga tradisi pelaksanaan upaca tumpek kandang (Tumpek Uye) dan tumpek bubuh (Tumpek Wariga). Ini dikarenakan masyarakat Desa Petiga sebagian besar memiliki atau memelihara ternak seperti sapi, babi dan ayam serta hampir seluruh masyarakatnya memiliki tegalan yang dijadikan tempat budidaya tanaman baik tanaman hias maupun tanaman palawija, sehingga tradisi upacara tumpek kandang dan tumpek bubuh sangat dikenal oleh seluruh kalangan masyarakat termasuk para siswa sekolah dasar. Tradisi ini sangat erat kaitannya dengan pelestarian lingkungan yang juga merupakan salah satu tema dalam pembelajaran di sekolah. Upacara tumpek wariga dan tumpek uye sesuai dengan tema "Peduli Terhadap Mahkluk Hidup" (Sudiana \& Sudirgayasa, 2015), Namun selama ini guru tidak pernah menggunakan tradisi ini sebagai bahan ajar.

Dari hasil observasi tersebut diketahui pada saat pembelajaran terlihat guru sudah berhasil dalam hal pemanfaatan media pada saat menyampaikan materi. Namun guru masih kurang maksimal pada saat menyampaikan materi di antaranya: (1) materi yang disampaikan masih bersifat konvensional atau terdahulu, tanpa mendapatkan informasi-informasi atau materi yang aktual atau terbaru, (2) hanya memberikan materi sebatas apa yang ada di dalam buku paket atau pegangan, (3) pembelajaran didominasi oleh guru, sehingga pembelajaran berpusat pada guru. Dalam proses pembelajaran belum merangsang kemterampilan berpikir siswa dan keterampilan proses. $\mathrm{Hal}$ ini mengindikasikan bahwa pelajaran IPA masih menekankan pada hafalan dan jarang melatih keterampilan berpikir tingkat tinggi siswa, sehingga kurang sejalan dengan tujuan pembelajaran IPA. Berdasarkan hasil wawancara terhadap guru kelas IV di SDN 1 dan SDN 3 Petiga, ternyata rata-rata hasil belajar IPA siswa masih rendah (nilai rata-rata 70) dibandingkan dengan KKM IPA SD itu sendiri yaitu 75. Hasil tinjauan dokumen buku nilai siswa (leger) terlihat bahwa rendahnya hasil belajar bersumber pada ranah kognitif dan psikomotor. Ranah kognitif dalam pelajaran IPA mengarahkan siswa untuk 
mempunyai kemampuan berpikir tingkat tinggi yang salah satunya adalah berpikir kritis, sedangkan ranah psikomotor IPA mengarahkan siswanya untuk terampil dalam menemukan suatu konsep dengan metode ilmiah, ketika kedua hal ini terintegrasi dalam diri siswa maka siswa tersebut akan mampu memecahkan masalah secara logis.

Untuk mengatasi permasalahan rendahnya pencapaian siswa pada ranah kognitif yaitu kemampuan berpikir kritis dan keterampilan proses serta ketidak sesuaian model pembelajaran yang digunakan di kelas dengan tujuan pembelajaran IPA di sekolah dasar, maka diperlukan upaya untuk memperbaiki kualitas pembelajaran agar dapat meningkatkan keterampilan berpikir kritis dan keterampilan proses siswa. Menurut Widiana, dkk (2015), berpikir kritis adalah kemampuan untuk memecahkan masalah yang dihadapi oleh seseorang. Agar mampu memecahkan masalah dengan baik dituntut kemampuan analisis, sintesis, evaluasi, generalisasi, membandingkan, mendeduksi, mengklasifikasi informasi, menyimpulkan, dan mengambil keputusan.

Salah satu alternatif model pembelajaran IPA yang dapat diterapkan untuk meningkatkan keterampilan berpikir kritis siswa dan memungkinkan siswa mengembangkan keterampilan proses adalah menggunakan model pembelajaran siklus belajar 7E berbasis kearifan lokal. Model siklus belajar 7E berbasis kearifan lokal memberikan lebih banyak kesempatan pada siswa untuk mengembangkan kemampuan berpikir dan keterampilan proses pada setiap tahap pembelajarannya. Tahap pembelajarannya terdiri dari Model siklus belajar 7E ini terbagi ke dalam 7 tahapan yaitu: elicit, engage, explore, explain, elaborate, evaluate dan extend.

\section{METODE}

Mengingat tidak semua variabel (gejala yang muncul) dan kondisi eksperimen dapat diatur dan dikontrol secara ketat, maka penelitian ini dikategorikan penelitian semu (penelitian quasi eksperimen). Rancangan yang digunakan adalah rancangan atau desain kelompok kontrol pretest posttest (The pretestposttest Control Group Design) (Millan, 2001).

Populasi dalam penelitian ini adalah siswa kelas IV di gugus II Kecamatan Marga, Kabupaten Tabanan yang berjumlah 71 orang. Adapun sampel yang digunakan dalam penelitian ini adalah 4 kelas yaitu 2 kelas sebagai eksperimen dan 2 kelas sebagai kontrol dengan jumlah sampel sebanyak 58 orang.

Instrumen yang digunakan untuk mengumpulkan data kemampuan berpikir kritis dan keterampilan proses berupa tes kemampuan berpikir kritis dan tes keterampilan proses. Data yang diperoleh kemudian dianalisis secara deskriptif dan inferensial.

\section{HASIL DAN PEMBAHASAN}

Berdasarkan hasil analisis data melalui statistik inferensial didapatkan hasil yaitu: 1) bahwa terdapat perbedaan kemampuan berpikir kritis siswa antara yang dibelajarkan dengan model siklus belajar 7E berbasis kearifan lokal dan yang dibelajarkan dengan model konvensional ( $F=55,023$ dan $p<0,05)$. Rata-rata kemampuan berpikir kritis siswa yang belajar dengan model siklus belajar 7E berbasis kearifan lokal (rata-rata $=75.65$ ) lebih besar dari rata-rata kemampuan berpikir kritis siswa yang belajar dengan model pembelajaran konvensional (rata-rata $=$ 60.00). 2) terdapat perbedaan keterampilan proses siswa antara yang dibelajarkan dengan model siklus belajar 7E berbasis lokal genius dan yang dibelajarkan dengan model konvensional $(F=54.089$ dan $p<0,05)$. Rata-rata keterampilan proses siswa yang belajar dengan model siklus belajar 7E berbasis kearifan lokal (ratarata $=80.32$ ) lebih besar dari rata-rata keterampilan proses siswa yang belajar dengan model pembelajaran konvensional (rata-rata $=64.35$ ). Hasil ini menunjukan bahwa pembelajaran dengan model siklus belajar 7E berbasis kearifan lokal dapat meningkatakan 
kemampuan berpikir kritis dan keterampilan proses siswa secara signifikan.

Dengan memadukan antara siklus belajar 7E yang memeberikan kesempatan siswa untuk lebih banyak melatihkan kemampuan berpikir kritis dan keterampilan proses, dan memanfaatkan kearifan lokal yaitu perayaan tumpek wariga dan tumpek uye yang sudah menjadi tradisi di daerah setempat, mampu memberikan pengalaman belajar yang bermakna bagi siswa sehingga lebih mudah bagi mereka untuk memahami materi pelajaran. Hasil penelitian ini sejalan dengan beberapa penelitian yang telah dilakukan oleh beberapa peneliti diantaranya: hasil penelitian Indriyani (2013) yang menyatakan bahwa adanya peningkatan siginifikan hasil belajar menggunakan pembelajaran LKS berbasis learning cycle 7E dalam pembelajaran fisika dapat mengembangkan keterampilan berpikir kritis siswa, hal serupa juga didapat oleh Buntod, Suksringam dan Singseevo (2010) yang menyatakan bahwa ada peningkatan signifikan pada prestasi belajar, keterampilan proses dan kemampuan berpikir kritis siswa yang dibelajarkan dengan model pembelajaran berbasis lingkungan. Hasil penelitian ini juga sejalan dengan pendapat Sudira (2011) yang menyatakan pengembangan pendidikan berbasis kearifan lokal Tri Hita Karana mendukung fundamental skill siswa.

\begin{tabular}{lrr}
\multicolumn{2}{c}{ Berdasarkan } & prinsip-prinsip \\
pokok THK yang menekankan & mandan \\
tumbuhnya kesadaran jiwa diatas \\
kesadaran ragawi \\
memanfaatkan potensi prana sabda,
\end{tabular} bayu, idep, maka siswa akan berkembang ketrampilan dasarnya (basic skill) berupa kemampuan dan kepekaannya dalam mendengarkan, menyimak, membaca, dan menulis. Di samping basic skill keterampilan fundamental yang juga dapat berkembang adalah ketrampilan berpikir (thinking skill) yaitu kecerdasan dan ketrampilan belajar, ketrampilan memecahkan masalah, mengembangkan dan menemukan solusi permasalahan, ketrampilan pengambilan keputusan, ketrampilan mengelola dan mengarahkan pikiran. Kemudian kualitas personal yaitu responsibilitas, moral, karakter, integritas, rasa percaya diri, loyalitas juga akan bisa tumbuh dengan baik sebagai bagian dari fundamental skill bagi siswa yang terdidik dalam lingkungan pendidikan berbasis THK.

Selanjutnya akan dibahas lebih terperinci mengapa secara operasional empiris model siklus belajar 7E berbasis kearifan lokal mampu meningkatkan kemampuan berpikir kritis dan keterampilan proses lebih baik daripada model pembelajaran konvensional. Setelah siklus belajar mengalami pengkhususan menjadi 5 tahapan, maka Eisenkraft (2003) mengembangkan siklus belajar menjadi 7 tahapan. Perubahan yang terjadi pada tahapan siklus belajar 5E menjadi $7 \mathrm{E}$ pada tahapan Engage menjadi 2 tahapan, yaitu Elicit dan Engage, sedangkan pada tahapan Elaborate dan Evaluate menjadi 3 tahapan, yaitu menjadi Elaborate, Evaluate dan Extend. Beranjak dari komparasi secara teoritik dan empiris antara model siklus belajar 7E dengan model pembelajaran konvensional. Model siklus belajar 7E didasari oleh paham konstruktivistik yang menganggap bahwa dalam belajar siswa aktif membangun pengetahuan sendiri dalam benaknya. Berdasarkan hal itu dapat dikatakan bahwa pengalaman belajar yang diperoleh siswa pada model siklus belajar 7E sangat memotivasi siswa dalam mengembangkan kemampuan berpikir tingkat tingi yaitu kemampuan berpikir kritis. Penambahan atau pengintegrasian kearifan lokal pada model pembelajaran ini juga sangat mendukung pengembangan kemampuan berpikir kritis dan keterampilan proses siswa. Karifan lokal yang sudah siswa lakukan selama ini dijadikan sarana dalam menyampaikan materi pelajaran sehingga siswa lebih mudah memahami materi tersebut. Dalam hal ini kearifan lokal yang digunakan adalah tradisi upacara 
tumpek kandang dan tumpek bubuh. Siswa menjadi tahu makna dari pelaksanaan upacara tersebut dan mampu membuat kaitan antara upacara tersebut dan dampaknya pada pelestarian lingkungan. Dalam proses mengaitkan antara upacara tumpek kandang dan tumpek wariga dengan dampaknya bagi hubungan antara manusia alam sekitar, siswa dirangsang untuk melatihkan indikator-indikator berpikir kritis seperti merumuskan masalah, memberikan argument, melakukan deduksi, melakukan induksi, evaluasi dan memutuskan dan melaksanakan. Pengintegrasian kearifan lokal pada proses pembelajaran membuat siswa mengetahui makna dari materi yang dibelajarkan dan secara tidak langsung membuat siswa lebih tertarik untuk belajar, sehingga kolaborasi antara model siklus belajar $7 \mathrm{E}$ dan kearifan lokal dalam hal ini upacara tumpek kandang dan tumpek bubuh lebih baik digunakan meningkatkan keterampilan berpikir kritis dan keterampilan proses siswa dibandingkan dengan model pembelajaran konvensional. Selain itu model siklus belajar 7E memiliki tahaptahap pembelajaran yang lebih kompleks daripada model pembelajaran langsung. Seperti diketahui siklus belajar 7E terdiri dari 7 tahap, yaitu tahap elicit, engage, explore, explain, elaborate, evaluate, dan extend. Dalam siklus belajar 7E memuat kegiatan pembelajaran seperti yang ditekankan pada Peraturan Menteri Pendidikan Nasional Republik Indonesia Nomor 41 Tahun 2007 tentang Standar Proses yaitu kegiatan inti eksplorasi, elaborasi dan konfirmasi. Dengan kata lain siklus belajar 7E merupakan perluasan dari kegiatan pembelajaran yang digunakan oleh sistem pendidikan Indonesia saat ini yang. Pelaksanaan tahap-tahap model siklus belajar 7E ini dapat memberikan kesempatan yang luas bagi siswa untuk mengembangkan indikatorindikator kemampuan berpikir kritis dan keterampilan proses siswa.

Pada tahap elicit, pengetahuan awal siswa akan digali sehingga siswa dapat mengembangkan ide-ide yang telah dimiliki pada tahap selanjutnya. Pada tahap engage, siswa dimotivasi untuk mengetahui lebih banyak materi yang akan dipelajari dengan cara menghadapkan siswa dengan suatu fenomena yang bertentangan dengan kognitif mereka. Pada tahap exsplore siswa diajak menemukan konsep dengan melakukan eksperimen. Pada tahap explain siswa dilatih untuk mengkomunikasikan hasil penemuannya. Pada tahap elaborate siswa dibimbing untuk mengaitkan konsep yang telah dipelajari untuk memecahkan masalah pada situasi yang berbeda. Pada tahap evaluate siswa dievaluasi pemahaman dan keterampilannya. Pada tahap extend siswa diatih mencari, menemukan dan menjelaskan contoh penerapan konsep serta mencari hubungan konsep yang dipelajari dengan konsep lain yang sudah atau belum mereka pelajari. Melalui tahap-tahap model siklus belajar 7E, siswa dibimbing dan diarahkan untuk memulai aktivitas dengan memanfaatkan pengetahuan awal siswa, melakukan pengamatan untuk membangun dasar pengetahuan siswa, membuat kaitan antara suatu kejadian dan dampak yang ditimbulkan, mengajukan hipotesis sebelum eksperimen, melakukan eksperimen, dan diakhiri dengan menarik kesimpulan serta menghubungkan konsep yang dipelajari dengan konsep lain. Tahaptahap model siklus belajar 7E berbasis kearifan lokal memberikan peluang bagi siswa untuk melatihkan kemampuan berpikir dan melatih keterampilan proses secara berulang-ulang.

Selain itu melalui implementasi model pembelajaran siklus belajar 7E berbasis kearifan lokal memberikan kesempatan kepada siswa untuk mengaitkan konsep-konsep yang sudah dipahami dengan konsep-konsep yang akan dipelajari sehingga terjadi proses belajar bermakna. Bermakna dalam hal ini siswa tahu tujuan mereka mempelajari konsep-konsep biologi dan menyadari perlunya mengembangkan keterampilan proses. Kebermaknaan materi atau konsep ini akan menumbuhkan rasa keperdulian 
terhadap lingkungan sekitar yang akan berdampak pada pelestarian lingkungan. Hasil penelitian ini sejalan dengan teori Ausebel tentang belajar bermakna (Meaningfull learning). Belajar dikatakan menjadi bermakna (meaningful learning) yang dikemukakan oleh Ausubel adalah bila informasi yang akan dipelajari siswa disusun sesuai dengan struktur kognitif yang dimiliki siswa itu sehingga siswa itu mampu mengaitkan informasi barunya dengan struktur kognitif yang dimilikinya (Hudoyo, 2008). Belajar seharusnya merupakan apa yang disebut asimilasi bermakna, materi yang dipelajari di asimilasikan dan dihubungkan dengan pengetahuan yang telah dipunyai sebelumnya.

Model pembelajaran siklus pembelajaran yang mampu melatih siswa mengemukakan gagasan yang sudah dimiliki, menguji serta mendiskusikan gagasan tersebut secara terbuka. Hal ini akan membuat siswa membangun konsep secara konstruktif, yang akhirnya akan memberi kontribusi pada peningkatan pemahaman konsep. Model pembelajaran siklus belajar 7E juga memberikan kesempatan kepada siswa untuk bekerja seperti ilmuwan, sehingga rasa ingin tahu siswa semakin berkembang dan memberikan kesempatan kepada siswa untuk menggunakan keterampilan proses, dengan kata lain melalui model pembelajaran siklus belajar 7E yang pembelajarannya berpusat pada siswa dapat memberikan peluang kepada siswa untuk mengembangkan sikap ilmiah dan keterampilan proses. Hasil penelitian ini sejalan dengan hasil penelitan Sornsakda (2009) di Thailand menyatakan bahwa model siklus belajar $7 \mathrm{E}$ dapat meningkatkan hasil belajar, keterampilan proses dan kemampuan berpikir kritis siswa. Hasil penelitian ini juga menunjukan adanya interaksi signifikan antara model pembelajaran terhadap hasil belajar, keterampilan proses dan kemampuan berpikir kritis. Sintak dalam pembelajaran 7E mampu mengorganisir kebutuhan dalam pembelajaran sains. Dengan adanya kesesuaian antara hakikat pembelajaran Sains/IPA dengan model siklus belajar 7E, maka wajar jika terdapat perbedaan pemahaman konsep dan keterampilan proses siswa yang diajar dengan model siklus belajar 7E dengan model pembelajaran konvensional. Dengan dilaluinya tahapan-tahapan tersebut, maka aspek kognitif, afektif, dan psikomotorik siswa dapat tergali dan ditingkatkan secara bersama.

Selain itu pengintegrasian kearifan lokal tumpek wariga dan tumpek uye merupakan hal yang turut berperan dalam peningkatan kemampuan berpikir kritis dan keterampilan proses siswa, hal inilah yang jarang dilakukan oleh guru dan sekaligus menjadi hal yang baru dalam penelitian ini. Pengintegrasian potensi setempat yang berupa kearifan lokal perlu ditingkatkan dalam proses pembelajaran. Penerapan model siklus belajar 7E berbasis kearifan lokal layak utnuk diterapkan dalam proses pembelajaran di sekolah dasar dalam kaitannya untuk meningkatkan kemampuan berpikir kritis dan keterampilan proses.

\section{SIMPULAN DAN SARAN}

Berdasarkan hasil penelitian dan pembahasan, maka dapat ditarik beberapa simpulan penelitian, yaitu: Rata-rata kemampuan berpikir kritis siswa yang belajar dengan model siklus belajar 7E berbasis kearifan lokal (ratarata $=75.65$ ) lebih besar dari rata-rata kemampuan berpikir kritis siswa yang belajar dengan model pembelajaran konvensional (rata-rata $=60.00$ ). Terdapat perbedaan kemampuan berpikir kritis siswa antara yang dibelajarkan dengan model siklus belajar 7E berbasis lokal genius dan yang dibelajarkan dengan model konvensional $(F=55,023$ dan $p<0,05)$. Rata-rata keterampilan proses siswa yang belajar dengan model siklus belajar 7E berbasis kearifan lokal (ratarata $=80.32$ ) lebih besar dari rata-rata keterampilan proses siswa yang belajar dengan model pembelajaran 
konvensional (rata-rata $=64.35$ ). Terdapat perbedaan keterampilan proses siswa antara yang dibelajarkan dengan model siklus belajar 7E berbasis lokal genius dan yang dibelajarkan dengan model konvensional $(F=54.089$ dan $\mathrm{p}<0,05)$.

Berdasarkan hasil penelitian ini, maka dapat diajukan beberapa saran guna peningkatan kualitas pembelajaran sains di sekolah. Hasil penelitian menunjukkan bahwa model siklus belajar 7E berbasis kearifan lokal lebih baik untuk meningkatkan kemampuan berpikir kritis dan keterampilan proses sains siswa. Untuk itu, kepada para guru yang disarankan agar menerapkan model siklus belajar 7E berbasis kearifan lokal dalam pembelajaran. Hal ini sangat penting untuk dilakukan mengingat kemampuan berpikir kritis dan keterampilan proses sangat perlu dilatihkan kepada siswa.

Peneliti menyadari bahwa perlakuan yang diberikan kepada siswa sangatlah singkat dan terbatas pada satu tema saja, hal ini terjadi karena keterbatasan peneliti pada pokok bahasan yang telah ditetapkan dan juga karena keterbatasan waktu yang dimiliki oleh peneliti. Untuk itu peneliti menyarankan, agar dilakukan kembali penelitian dengan model yang sama pada tema yang berbeda

\section{DAFTAR PUSTAKA}

Brooks J.G and Brooks M.G. (1999). In Search of Understanding The Case for Constructivist Classrooms. Alexandria. $\mathrm{Va}$ : ASCD.

Buntod, Phramaha Charoen, Suksringam, Paitun and Singseevo, Adisak. 2010. Effects of Learning Environmental Education on Science Process Skills and Critical Thinking of Mathayomsuksa 3 Students with Different Learning Achievements. Journal of Social Sciences. Vol. 6 (1)

Cabrera, G. A. (1992). A Framework For Evaluating the Teching of Critical
Thinking. Dalam R.N. Cassel (ed). Education. 113(1) 59-63

Chankian, Jeeraporn, Singseewo, Adisak and Thamsananupap, Penkae. Science Curriculum Development on Environmental Conservation, with an Emphasis on the Promotion of Critical Thinking Skills for Mathayomsuksa 1 Students. European Journal of Scientific Research. Vol.67 (4).

Costa, A.L. (Ed). Developing Minds A Resource Book for Teaching Thinking. Alexandra, Virginia: Assosiation for Supervisions and Curriculum Development (ASCD): 87-89

Eisenkraft, A. (2003). The Science Teacher: Expanding the $5 E$ Model. Arlington:National Science teacher Association.

Ennis, R.H. (1985). Goals for A Critical Thiking Curriculum. Costa, A.L. (Ed). Developing Minds A Resource Book for Teaching Thinking. Alexandra, Virginia: Assosiation for Supervisions and Curriculum Development (ASCD): 54-57.

Hamalik, Oemar. (2008). Kurikulum dan Pembelajaran. Jakarta: Bumi Aksara.

Hudoyo, H. (2008). Metode Teknik dan Strategi dalam Belajar. Bandung: Tarsito.

Indriyani, Irma Rosa. (2013). Pengembangan LKS Fisika Berbasis Siklus Belajar (Learning Cycle) 7E untuk Meningkatkan Hasil Belajar dan Mengembangkan Kemampuan Berpikir Kritis pada Siswa SMA Kelas $X$ Pokok Bahasan Elektromagnetik. Tesis. Universitas Ahmad Dahlan.

Jonson, Elaine B. (2010). Contextual Teaching and Learning: Menjadikan Belajar Mengajar Mengasikkan dan Bermakna. Bandung: Kaifa Learning. 
Soetarno. (2004). Ragam Budaya Indonesia. Direktorat Pembinaan Pendidik Tenaga Pendidikan dan Ketenagaan Perguruan Tinggi. Jakarta: Dirjen Dikti.

Sornsakda, S., Suksringarm, P. and Singseewo, A. (2009). Effects of Learning Environmental Education Using The 7E-Learning Cycle with Metacognitive Techniques and Teacher's Handbook Approaches on Learning Achievement, Integrated Science Process Skills and Critical Thinking of Mathayomsuksa 5 Students with Different Learning Achievement. Pakistan Journal of Social Sciences. 6(5): 297-303.

Sudiana, I Made. Sudirgayasa I Gede. (2015). Jurnal Kajian Bali. 5(1). 181-200.

Sudira P. (2011). Praksis tri hita karana dalam struktur dan kultur pendidikan karakter kejuruan pada SMK di Bali. Jurnal Pendidikan Karakter. Universitas Negeri Yogyakarta.

Widiana. (2015). Pengaruh Pendekatan Saintifik Dan Kemampuan Berpikir Kritis Terhadap Hasil Belajar Ipa . e-Journal PGSD Universitas Pendidikan Ganesha Jurusan PGSD Volume: 3 No: 1 Tahun 2015.

http://ejournal.undiksha.ac.id/inde x.php/JJPGSD/article/view/5637/ 4106 